\title{
Customer Loyalty Explained by Electronic Recovery Service Quality: Implications of the Customer Relationship Re-Establishment for Consumer Electronics E-Tailers
}

\author{
Kuang-Wen Wu \\ Feng Chia University \\ E-Mail: kwwu@fcu.edu.tw
}

\begin{abstract}
This non-experimental, causal study related to examine and explore the relationships among electronic service quality, customer satisfaction, electronics recovery service quality, and customer loyalty for consumer electronics e-tailers. This study adopted quota and snowball sampling. A total of 121 participants completed the online survey. Out of seven hypotheses in this study, five were supported, whereas two were not supported. Findings indicated that electronic recovery service quality had positive effect on customer loyalty. However, findings indicated that electronic recovery service quality had no effect on perceived value and customer satisfaction. Findings also indicated that perceived value and customer satisfaction were two significant variables that mediated the relationships between electronic service quality and customer loyalty. Moreover, this study found that electronic service quality had no direct effect on customer satisfaction, but had indirect positive effects on customer satisfaction for consumer electronics e-tailers. In terms of practical implications, consumer electronics e-tailers' managers could formulate a competitive strategy based on the modified Electronic Customer Relationship Re-Establishment model to retain current customers and to enhance customer relationship management (CRM). The limitations and recommendations for future research were also included in this study.
\end{abstract}

Keywords: Service Recovery, Customer Loyalty, E-S-QUAL, E-Tailer

\section{INTRODUCTION}

Electronic commerce has emerged as an increasingly significant business phenomenon in recent years (Sexton, Johnson, \& Hignite, 2002), and the experience 
of shopping in an online store is more technological than the non-electronic retail service experience. Using the Internet, customers browse Web sites to find merchandise, to search for merchandise information, and to compare prices. They are also able to determine when the items will be delivered and how to return merchandise. All of those experiences influence customers' expected and perceived e-tailer's service quality, and will ultimately influence their satisfaction and loyalty. However, almost $70 \%$ of customers who change their retail sales providers do not complain about price or product quality, but they have complained about the indifferent attitude of their former providers (Bennington \& Cummane, 1998). The WebTrack data also has shown that while a greater percentage of online-only retailers (33\%) responded to customer service e-mails within six hours than brick-and-mortar retailers (28\%), the pure-plays were less responsive overall (as cited in Cox, 2002). Meanwhile, findings from the Jupiter Executive Survey revealed that a majority of consumers (57\%) expressed that the speed of a retailer's response to customer service e-mail inquiries would affect their decision to make future purchases from a particular Web site (as cited in Cox, 2002). These consumers' responses indicate that service quality is one of the factors that influences customer satisfaction and retains customers in the competitive online market.

Service quality and customer satisfaction have been selected as research topics for forty years. However, the development of the Internet inspired the emergence of e-commerce in the past ten years. This new type of business has led to rethinking about the definition of business. The developers of SERVQUAL, Parasuraman, Zeithaml, and Berry (1988), also developed two new scales to show their interests in the new era. Unlike the SERVQUAL that was examined and applied in several studies, the E-S-QUAL and E-RecS-QUAL (Parasuraman, Zeithaml, \& Malhotra, 2005) are newly developed, and therefore need continued validation and application to different types of e-business.

In the satisfaction literature, Fornell, Johnson, Anderson, Cha, and Bryant (1996) have developed the American Customer Satisfaction Index model, which comprehensively identifies causal relationships among customer satisfaction and antecedents and consequences of customer satisfaction. However, this model has difficulty in explaining how firms deal with service failure and how to turn dissatisfied customers into loyal customers. It is necessary to add service recovery as an important variable into the model to help explain how a firm can improve customer satisfaction through service failure solution to turn dissatisfied customers into loyal customers. The purpose of this non-experimental, causal study was to examine and 
explore the relationships among electronic service quality, customer satisfaction, electronics recovery service quality, and customer loyalty for consumer electronics e-tailers by adopting the E-S-QUAL and E-RecS-QUAL.

\section{LITERATURE REVIEW}

\section{Electronic Service Quality and Service Recovery}

Self-service is an important concept to be applied to business-to-consumer e-commerce. Online shoppers look for items they want to purchase on the Internet, add items into an online basket, and click the submit button to send an order to online stores. The growing level of online sales every year is the evidence that consumers increasingly prefer to "help themselves" and demand to obtain instant information (Bonde \& Cahill, 2005). Time saving is the biggest advantage of self-service according to $50 \%$ of 1,008 survey respondents, whereas lack of human contact is the biggest disadvantage of self-service by $43 \%$ of respondents (Howard \& Worboys, 2003).

Like a shop window for a physical retail store, a Web page is an essential element for a virtual store. However, an online store not only needs a fancy, informative Web page, but also requires a reliable system to support the operation. A study conducted by the Boston Consulting Group indicates that $48 \%$ of respondents cite slow response time as the main reason for abandoned online transactions (as cited in Teeter \& Schointuch, 2000).

Zeithaml, Parasuraman, and Malhotra (2000) developed 11 e-SQ dimensions for measuring perceived e-service quality through a three-stage process using exploratory focus groups and two phases of empirical data collection and analysis. Their purpose was to develop a conceptual framework to understand e-service quality. These scholars also suggested that the 11 e-SQ dimensions should be continually examined and improved (Zeithaml, Parasuraman, \& Malhotra, 2002). Parasuraman, Zeithaml, and Malhotra (2005) refined the e-SQ scale and developed two sets of scales for measuring electronic service quality. One is called the E-Core Service Quality Scale (E-S-QUAL), consisting of 22 items to measure four dimensions: efficiency, system availability, fulfillment, and privacy. Another is called the E-Recovery Service Quality Scale (E-RecS-QUAL), consisting of 11 items to measure three dimensions: responsiveness, compensation, and contact. These scholars declared that the $E-R e c-Q U A L$ scale is a subset scale of the E-S-QUAL scale.

The E-S-QUAL and E-RecS-QUAL scales were successfully tested in a study using a quota-sampling method. One-third of respondents were asked to evaluate their 
favorite sites, one-third were asked to evaluate their second-favorite sites, and one-third were asked to evaluate their third-favorite sites (Parasuraman et al., 2005). There were 549 completed questionnaires from randomly selected Web users. However, Parasuraman et al. (2005) suggested that the reliability and validity of $E-R e c S-Q U A L$ needed further examination in the context of Web sites having a higher incidence of problem encounters. These scholars also suggested that these two scales may be modified to measure service quality of pure-service sites because their research focused on Web sites that sold physical products.

Service recovery can be regarded as a passive strategy for the improvement of customer satisfaction. Service recovery refers to the actions taken by a firm in response to a service failure (Zeithaml \& Bitner, 2003). Service failure often occurs when the customer's perceived service quality falls below customer expectations. For example, delivery and Web site design problems are two major types of service failure in online retailing (Holloway \& Beatty, 2003). Such failures may cause significant costs to the firm, such as lost customers and negative word of mouth (Bitner, Brown, \& Meuter, 2000).

Literature has addressed the importance of service recovery. According to Hart, Heskett, and Sasser (1990), firms learn from experiences of service recovery when they may not be able to prevent service failure. Berry and Parasuraman (1992) believed that firms should not regard service failure as a problem but as an opportunity to create satisfied customers. Hence, recovery strategies have a dramatic impact on a firm's revenue and profitability (Tax \& Brown, 1998). Service recovery literature has shown that resolving customer problems has a strong impact on customer satisfaction and loyalty (Miller, Craighead, \& Karwan, 2000; Smith \& Bolton, 2002). Swanson and Kelley (2001) also found that customer behavioral intentions are more favorable when customers believe that firms consistently implement service recovery when failures occur. Furthermore, Robbins and Miller (2004) found that well-handled service recovery strongly affects customer loyalty.

Hypothesis 1. Electronic recovery service quality has a direct positive effect on Electronic service quality for consumer electronics e-tailers.

Hypothesis 2. Electronic recovery service quality has a direct positive effect on customer satisfaction for consumer electronics e-tailers.

Hypothesis 3. Electronic recovery service quality has a direct positive effect on customer loyalty for consumer electronics e-tailers. 


\section{Perceived Value and Satisfaction}

An early pioneer in the study of equity, George Homans stated that the essence of equity was contained in a "rule of justice" (as cited in Oliver, 1997). In fundamental terms, equity is an evaluation of fairness, rightness, or deservingness that customers make in reference to what others receive (Oliver, 1997). In the satisfaction literature, equity theory considers the ratio of the customer's perceived outcome/input to that of the service provider's outcome/input (Oliver \& DeSarbo, 1988). Bolton and Lemon (1999) extended this concept of outcome/input to the perspective of perceived value. They declared that equity referred to customers' evaluation of the perceived sacrifice (input) of the offering (outcome). Perceived sacrifices include purchase price and other possible costs such as time consumption (Yang, 2001). A positive perception of value may bring customers back to make another transaction (Minocha, Dawson, Blandford, \& Millard, 2005). When customers believe they are being treated fairly in an exchange, they will be satisfied with the transaction if their outcome-to-input ratio is in some sense adequate (Oliver \& DeSarbo, 1988). Fredericks and Salter (1998) pointed out that quality, price, and company or brand image were three factors that comprise the customer value package. In other words, customers will make an explicit comparison between what they give and what they get. The positive relationship between equity and satisfaction was supported in the literature (Oliver, 1993; Oliver \& Swan, 1989a, 1989b). However, customers expect prices to be lower in an online store than in a traditional sales channel (Karlsson, Kuttainen, Pitt, \& Spyropoulou, 2005). They may expect to get more value from an online store than from a physical store.

Hypothesis 4. Electronic service quality has a direct positive effect on perceived value for consumer electronics e-tailers.

Hypothesis 5. Perceived value has a direct positive effect on customer satisfaction for consumer electronics e-tailers.

\section{Service Quality, Customer Satisfaction, and Loyalty}

Bloemer and Ruyter (1998) suggested that store loyalty resulted from a consumer committed to the store through an explicit and extensive decision-making process. Customer loyalty is frequently operated as a conscious evaluation of the price/quality ratio or the willingness to pay a premium price, or alternatively price indifference (Raju, Srinivasan, \& Lal, 1990; Zeithaml, Berry, \& Parasuraman, 1996). Supphellen and Nysveen (2001) suggested that corporate brand loyalty affected online shoppers' intentions to revisit the Web site. 
Cronin and Taylor (1992) examined the causal relationships among service quality, customer satisfaction, and purchase intention. Each variable was measured by one item. There were 660 usable questionnaires randomly collected from customers of four types of businesses in the southeastern United States: banking, pest control, dry cleaning, and fast food. The results of correlation analysis have suggested that (1) service quality was an antecedent of consumer satisfaction, (2) service quality had less effect on purchase intentions than did consumer satisfaction, and (3) consumer satisfaction had a significant effect on purchase intentions.

Dabholkar, Shepherd, and Thorpe (2000) also found that customer satisfaction strongly mediated the effect of service quality on behavioral intentions. The data used in their study were systematically randomly collected from 397 churches. A test of discriminant validity revealed that the construct of service quality was different from the construct of customer satisfaction. The result of regression analysis in structural equations modeling supported their proposition that customer satisfaction had a stronger effect on behavioral intentions than service quality did (Dabholkar et al., 2000).

Service quality literature indicated that perceptions of high service quality and high service satisfaction resulted in a very high level of purchase intentions (Boulding, Kalra, Staelin, \& Zeithaml, 1993; Cronin \& Taylor, 1992; Taylor, 1997; Taylor \& Baker, 1994; Zeithaml et al., 1996). Cöner and Güngör (2002) claimed that customer loyalty was affected by product quality, service quality, and retailer image. They also suggested "quality [of product and service] ... is directly related to customer satisfaction, and ... lead[s] to the loyalty of the customer" (Cöner \& Güngör, 2002, p. 195). Customer satisfaction literature showed that the relationship between customer satisfaction and customer loyalty depended on the type of satisfaction. The positive impact of manifest satisfaction on customer loyalty was stronger than that of latent satisfaction on customer loyalty (Bloemer \& Kasper, 1995; Bloemer \& Ruyter, 1998). Based on empirical findings in service quality and satisfaction literature, service quality is one of the antecedents of satisfaction (Anderson \& Sullivan, 1993; Cronin \& Taylor, 1992, 1994; Reidenbach \& Sandifer-Smallwood, 1990; Spreng \& Mackoy, 1996; Woodside, Frey, \& Daly, 1989), and loyalty is one of the consequences of satisfaction (Cöner \& Güngör, 2002; Cronin \& Taylor, 1992, 1994; Dabholkar, Shepherd, \& Thorpe, 2000). Luarn and Lin (2004) tested their hypothesized customer loyalty model and found that customer satisfaction, perceived value, and customer loyalty were different constructs. Their findings indicated that not only customer satisfaction and perceived value directly affected customer loyalty, but also indirectly 
affected customer loyalty through commitment.

Hypothesis 6. Electronic service quality has a direct positive effect on customer satisfaction for consumer electronics e-tailers.

Hypothesis 7. Customer satisfaction has a direct positive effect on customer loyalty for consumer electronics e-tailers.

\section{METHODOLOGY}

\section{Target Population}

The target population includes a set of people or events to which researchers wish to generalize the results of their study (Romano, 2004). In this study, the target population included all American online shoppers who had ever purchased consumer electronics products on the Internet. It is difficult to calculate an exact number of the target population because the size of the consumer electronics market is presented by the amount of dollar sales. In this study, the number of the target population was estimated by dividing the number of annual online consumer electronics sales by the number of average online spending per year per online shopper. Online sales reached $\$ 141.4$ billion in 2004 (Millard, 2005), and online consumer electronics sales accounted for $6 \%$ of total online sales (Miller, 2001). The average online spending per person in the first half of 2004 was nearly $\$ 580$ (Kerner, 2004). The average online shopping frequency was 1.34 times per month (Turow, Feldman, \& Meltzer, 2005) or nearly 16 times per year, per online shopper. Therefore, the estimated number of target population is 177,500 online shoppers of consumer electronics.

\section{Accessible Population}

The accessible population is a subset of the target population that is accessible to a researcher because of geographic, temporal, or cultural characteristics (Romano, 2004). In this study, the accessible population was limited to online consumer electronics shoppers who could be reached by e-mail, but its number was unknown because it is nearly impossible to know the number of e-mails forwarded by e-mail receivers. 
Table 1 The Quota Characteristics and Size of the Initial Sample

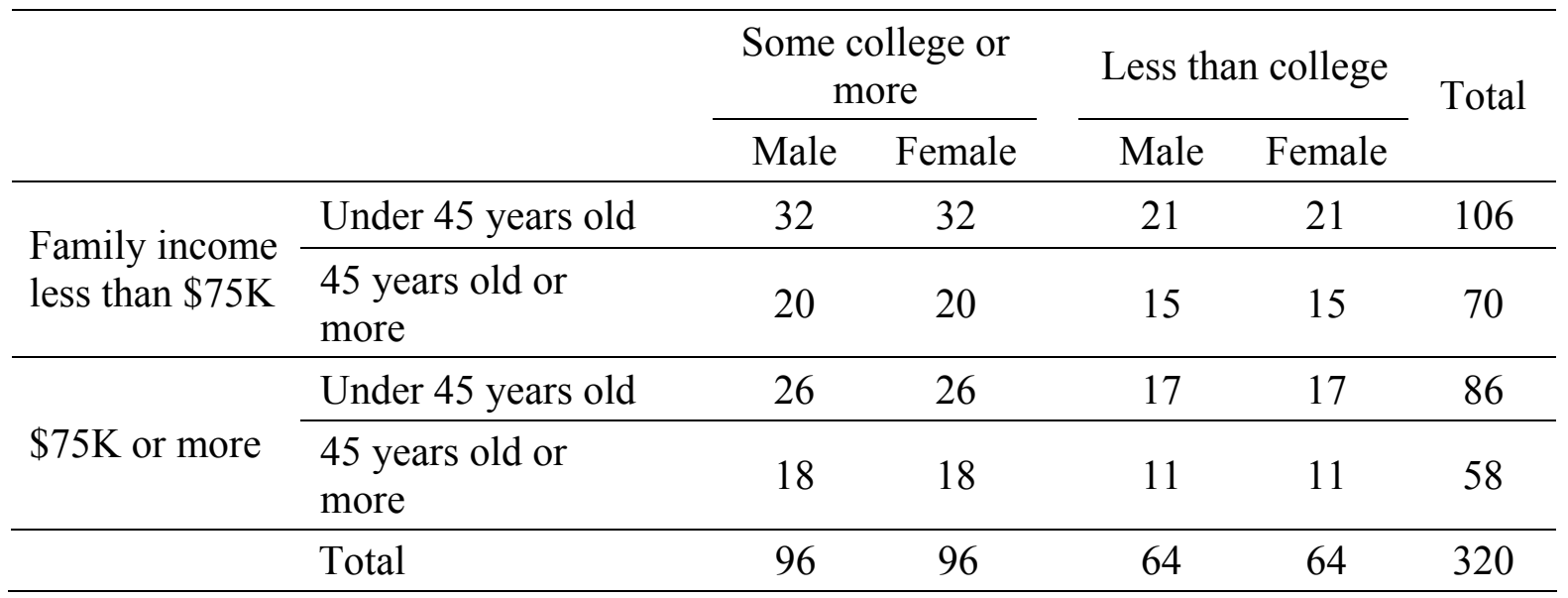

Note: The initial quota sample was distributed according to the following characteristics: $50 \%$ male, $60 \%$ under 45 years old, $60 \%$ with some college or more, and $55 \%$ with family income less than $\$ 75,000$.

\section{Quota and Snowball Sampling Plan}

Two non-random sampling techniques were used for this study. The sampling method is one of the factors affecting sampling error. The greater the sampling error, the less accurate the estimation of the population values (Grossnickle \& Raskin, 2001). As a result, random samples are always preferable to nonrandom samples. However, random samples are not always available, affordable, or efficient. Online shoppers are more difficult to identify compared to traditional shoppers; therefore, non-random snowball sampling was used to access the population. Furthermore, in order to enhance the representativeness of the sample, quota sampling was used. Quota sampling is another non-random sampling technique closely paralleling stratified sampling (random sampling) (StatPat Inc., 2005).

The sample of this study was selected from online consumer electronics shoppers who received the e-mail invitations to do an online survey. A snowball sampling method was used for this study to access the initial sample. "Snowball or referral sampling is used when the population being researched is difficult to reach" (Grossnickle \& Raskin, 2001, p. 126). The method relies on finding initial respondents who fit the profile for the study, contacting them, asking them to participate in the study, and asking them to refer other qualified potential respondents.

The initial group of respondents of the snowball was a non-random "quota" sample, selected to represent the population. The strengths of the snowball sampling are cost-efficiency and time-saving. Snowball sampling allows researchers to reach the potential qualified respondents by the distribution of interpersonal relationships. 
By initially starting with a quota sample, to represent various subpopulations in the target population, it may be possible that the final data-producing sample closely represents the target population, thereby strengthening the external validity of study findings.

The demographic profile of the initial quota sample was determined based on the characteristics of U.S. adult Internet users presented in the research by Turow, Feldman, and Meltzer in 2005. From their research, the characteristics of U.S. adult Internet users are $48 \%$ male, $59 \%$ under 45 years old, $61 \%$ some college or more, and $55 \%$ family income less than $\$ 75,000$. The demographics of the online consumers in the United States from a study by InsightExpress were similar to the characteristics of U.S. adult Internet users (as cited in Girard, Korgaonkar, \& Silverblatt, 2003). In this study, the initial quota sample of 320 people selected by the researcher was based on the quota characteristics. Table 1 represents the quota characteristics of the initial sample. The first order quota, snowball sample consisted of people who received e-mail invitations from the initial sample. The second order snowball sample consisted of people who received e-mail invitations from the first order snowball samples. The start date for data collection was August 4, 2005 and the completion date was October $3,2005$.

\section{Instrumentation and Data Analysis Method}

Some constructs cannot be observed directly in the social science field, and so the researcher has to use scales to measure the theoretical constructs. The theoretical phenomena that scales intend to measure are often called latent variables, while the measured behavior scores are termed observed or manifest variables (Byrne, 2001). The instruments used to measure latent variables are usually in a form of self-reporting questionnaires. This study required measures of five latent variables: electronic service quality, electronic recovery service quality, perceived value, customer satisfaction, and customer loyalty. All instruments were adapted from existing scales. The survey instruments included Perceived Value Scale, E-S-QUAL, E-RecS-QUAL, Customer Satisfaction Scale, and Customer Loyalty Scale of Behavioral-Intentions Battery. The data collected from the online survey were analyzed by using the statistical software of SPSS 11.5 and AMOS 5.0. The methods of data analysis included descriptive statistics, exploratory factor analysis, and structural equation modeling (SEM) analysis. 


\section{RESULTS}

\section{Socio-Demographic Characteristics of the Final Data-Producing Sample}

Among the 359 respondents who participated in the online survey, 20 respondents had not lived in the continental United States for at least six months in the past year, 52 respondents had not purchased online electronic products within the past year, nine respondents did not finish the online survey, and two respondents had made their last purchase more than one year ago, 155 respondents had no negative experience in online purchasing. This resulted in a total of 121 valid responses used in the data analysis procedures.

The respondents consisted of $62.5 \%$ males and $37.5 \%$ female, with an age range from 18 to 75 . The average of the respondents' age was 37.08, with a standard deviation of 11.5 years. The largest age group of respondents was between 26 and 35 years old (40.8\%) and the smallest age group was 56 years old or more (7.5\%). Of all respondents, more than $90 \%$ completed some higher education. The largest educational group was "four-year college graduate" $(42.1 \%)$, whereas the second largest educational group, which was slightly fewer than the largest group, was "professional/graduate" (33.1\%). The largest group of annual household income was between $\$ 60,000$ and $\$ 74,999$ (23.1\%), with $61.9 \%$ of respondents' annual household income being less than $\$ 75,000$ and $38.1 \%$ of that being more than $\$ 75,000$. Table 2 presents the frequency distribution of the respondents' gender, age, education, and annual household income.

The socio-demographic characteristics of the final data-producing sample were $62 \%$ male, $79 \%$ under 45 years old, $92 \%$ some college or more, and $62 \%$ family income less than $\$ 75,000$. To assess the representativeness of the final data-producing sample with the target population, and implications for external validity, the percentage difference in four demographic characteristics between the data-producing sample and the initial quota sample were analyzed. For the characteristic of gender, the percentage difference was $12 \%$. For the characteristic of age, the percentage difference was 19\% (under-representing those 45 and over). For the characteristic of education, the percentage difference was 32\% (under-representing those with less than some college). For the characteristic of family income, the percentage difference was $7 \%$. The results indicated that the characteristics of the final data-producing sample in gender and family income had good representativeness with the initial quota sample, but not with the characteristics of age and education. Table 3 presents the comparison of characteristics of the initial quota sample with the final data-producing sample. 
Table 2 Socio-Demographic Characteristics of the Sample by Gender, Age, Education and Annual Household Income

\begin{tabular}{|c|c|c|}
\hline Demographic variables & Frequency & Valid percentage \\
\hline \multicolumn{3}{|l|}{ Gender $(n=120)$} \\
\hline Male & 75 & $62.5 \%$ \\
\hline Female & 45 & $37.5 \%$ \\
\hline \multicolumn{3}{|l|}{$\operatorname{Age}^{a}(n=120)$} \\
\hline $18-25$ & 15 & $12.5 \%$ \\
\hline $26-35$ & 49 & $40.8 \%$ \\
\hline $36-45$ & 31 & $25.8 \%$ \\
\hline $46-55$ & 16 & $13.4 \%$ \\
\hline 56 or more & 9 & $7.5 \%$ \\
\hline \multicolumn{3}{|l|}{ Hollingshead's Education Scale $(\mathrm{n}=121)$} \\
\hline 1. Professional/Graduate & 40 & $33.1 \%$ \\
\hline 2. Four-year college graduate & 51 & $42.1 \%$ \\
\hline 3. One to three years college & 21 & $17.4 \%$ \\
\hline 4. High school graduate & 9 & $7.4 \%$ \\
\hline \multicolumn{3}{|l|}{ Annual Household Income $(n=121)$} \\
\hline Less than $\$ 30,000$ & 12 & $9.9 \%$ \\
\hline$\$ 30,000-\$ 44,999$ & 13 & $10.7 \%$ \\
\hline$\$ 45,000-\$ 59,999$ & 22 & $18.2 \%$ \\
\hline$\$ 60,000-\$ 74,999$ & 28 & $23.1 \%$ \\
\hline$\$ 75,000-\$ 89,999$ & 14 & $11.6 \%$ \\
\hline$\$ 90,000-\$ 104,999$ & 7 & $5.8 \%$ \\
\hline$\$ 105,000-\$ 119,999$ & 7 & $5.8 \%$ \\
\hline$\$ 120,000$ or more & 18 & $14.9 \%$ \\
\hline
\end{tabular}

${ }^{\text {a }}$ The average age was 37.08 years old, and the standard deviation is 11.5 .

\section{Reliability and Validity of Scales}

The reliability of scales used in this study was calculated by Cronbach's coefficient alpha. The coefficient alpha values exceeded the minimum standard of .7 (Nunnally \& Bernstein, 1994), providing good estimates of internal consistency reliability. As shown in Table 4, coefficient alpha values ranged from .91 to .97 for the four dimensions of electronic service quality, from .87 to .96 for the three dimensions of electronic recovery service quality, and from .88 to .96 for other constructs. All constructs obtained an acceptable level of a coefficient alpha above .70 , indicating that the scales used in this study were reliable. 
The estimates of standardized factor loadings were used to determine the convergent validity of scales. The minimum factor loading in the confirmatory factor analysis for items in this study was .79 (see Table 4). Because each factor loading on each construct was more than .50, the convergent validity for each construct in this study was established (Hair, Anderson, Tatham, \& Black, 1998).

Table 3 Comparison of Characteristics of Initial Quota Sample with Final Data-Producing Sample

\begin{tabular}{|c|c|c|c|c|c|}
\hline Variable & $\begin{array}{c}\text { Quota } \\
\text { sample } \\
(\mathrm{N}=320)\end{array}$ & $\begin{array}{c}\text { Quota } \\
\text { sample } \\
(\%)\end{array}$ & $\begin{array}{c}\begin{array}{c}\text { Final data- } \\
\text { producing } \\
\text { sample }\end{array} \\
(\mathrm{N}=120-121)\end{array}$ & $\begin{array}{l}\text { Final data- } \\
\text { producing } \\
\text { sample } \\
(\%)\end{array}$ & $\begin{array}{c}\text { Percentage } \\
\text { difference } \\
\text { (data- producing } \\
\text { sample- quota } \\
\text { sample) }\end{array}$ \\
\hline Age & & & $\mathrm{n}=120$ & & \\
\hline Under 45 & 192 & $60 \%$ & 95 & $79 \%$ & $+19 \%$ \\
\hline 45 and older & 128 & $40 \%$ & 25 & $21 \%$ & $-19 \%$ \\
\hline Gender & & & $\mathrm{n}=120$ & & \\
\hline Male & 160 & $50 \%$ & 75 & $62 \%$ & $+12 \%$ \\
\hline Female & 160 & $50 \%$ & 45 & $38 \%$ & $-12 \%$ \\
\hline Education & & & $\mathrm{n}=121$ & & \\
\hline No college & 128 & $40 \%$ & 9 & $8 \%$ & $-32 \%$ \\
\hline $\begin{array}{l}\text { Some college } \\
\text { or more }\end{array}$ & 192 & $60 \%$ & 112 & $92 \%$ & $+32 \%$ \\
\hline Family Income & & & $\mathrm{n}=121$ & & \\
\hline $\begin{array}{l}\text { Less than } \\
\$ 75 \mathrm{~K}\end{array}$ & 176 & $55 \%$ & 75 & $62 \%$ & $+7 \%$ \\
\hline$\$ 75 \mathrm{~K}$ or more & 144 & $45 \%$ & 46 & $38 \%$ & $-7 \%$ \\
\hline
\end{tabular}

Table 4 Reliability of Scales and Item-Construct Loadings Construct / Factor / Item Factor Loading

\begin{tabular}{ll}
\hline Electronic Service Quality (E-S-QUAL) & \\
\hline Efficiency (Cronbach's alpha $=.96)$ & .87 \\
\hline Easy to find what I need & .91 \\
\hline Easy to get anywhere on the site & .89 \\
\hline Enable to complete a transaction quickly & .94 \\
\hline Well-organized information & .90 \\
\hline Load Web page fast & .86 \\
\hline Simple to use & .91 \\
\hline Enable to get on to it quickly & .86 \\
\hline Well-organized Web page &
\end{tabular}


Table 4 Reliability of Scales and Item-Construct Loadings (Continued) Construct / Factor / Item Factor Loading

\begin{tabular}{|c|c|}
\hline \multicolumn{2}{|l|}{ System Availability $($ Cronbach's alpha $=.91)$} \\
\hline Always available for business & .88 \\
\hline Launch and run right away & .85 \\
\hline Does not crash & .88 \\
\hline Pages do not freeze after enter order information & .83 \\
\hline \multicolumn{2}{|l|}{ Fulfillment $($ Cronbach's alpha $=.97)$} \\
\hline Deliver orders when promised & .97 \\
\hline Make items available for delivery within a suitable time frame & .93 \\
\hline Quickly deliver & .92 \\
\hline Send out the items ordered & .93 \\
\hline Has in stock items that the company claims to have & .87 \\
\hline Truthful about its offerings & .90 \\
\hline Make items available for delivery within a suitable time frame & .93 \\
\hline \multicolumn{2}{|l|}{ Privacy (Cronbach's alpha $=.93$ ) } \\
\hline Protects information about shopping behavior & .92 \\
\hline Does not share personal information with other sites & .90 \\
\hline Protect credit card information & .92 \\
\hline \multicolumn{2}{|l|}{ Electronic Recovery Service Quality (E-RecS-QUAL) } \\
\hline \multicolumn{2}{|l|}{ Responsiveness $($ Cronbach's alpha $=.94)$} \\
\hline Provide with convenient options for returning items & .90 \\
\hline Handle product returns well & .88 \\
\hline Offer a meaningful guarantee & .87 \\
\hline Tell what to do if transaction is not processed & .85 \\
\hline Take care of problems promptly & .93 \\
\hline \multicolumn{2}{|l|}{ Compensation (Cronbach's alpha $=.92)$} \\
\hline Compensate for problems & .88 \\
\hline Compensate when ordered items don't arrive on time & .94 \\
\hline Pick up return items from home or business & .90 \\
\hline \multicolumn{2}{|l|}{ Contact (Cronbach's alpha $=.87)$} \\
\hline Provide a telephone number to reach the company & .83 \\
\hline Customer service representatives are available online & .82 \\
\hline Offer the ability to speak to a live person if there is a problem & .84 \\
\hline \multicolumn{2}{|l|}{ Perceived Value $($ Cronbach's alpha $=.96)$} \\
\hline Price & .89 \\
\hline Overall value & .96 \\
\hline Perceived control & .93 \\
\hline Perceived convenience & .96 \\
\hline
\end{tabular}


Table 4 Reliability of Scales and Item-Construct Loadings (Continued)

Construct / Factor / Item

Factor Loading

\begin{tabular}{ll}
\hline Customer Satisfaction (Cronbach's alpha $=.88)$ & .81 \\
\hline Most recent experience & .95 \\
\hline Compare with expectations & .79 \\
\hline Compare with the ideal Web site & .89 \\
\hline Customer Loyalty (Cronbach's alpha $=.93)$ & .88 \\
\hline Positive word-of-mouth & .92 \\
\hline Recommend to others & .79 \\
\hline Encourage others to use & .82 \\
\hline First choice for future &
\end{tabular}

Table 5 Goodness-of-Fit Results of the Hypothesized Model

\begin{tabular}{lccc}
\hline \multicolumn{1}{c}{ Goodness-of-fit statistics } & & Values & $\begin{array}{c}\text { Desired range } \\
\text { of values for a } \\
\text { good fit }\end{array}$ \\
\hline Absolute fit measures & & & \\
\hline Chi-square test & $\chi^{2}$ & 5.24 & \\
& & $p>.05)$ & $p>.05$ \\
\hline Degrees of freedom & $\mathrm{df}$ & 3 & $\geq 0$ \\
\hline Chi-square / degrees of freedom ratio & $\chi^{2} / \mathrm{df}$ & 1.75 & 2 to 5 \\
\hline Goodness of fit index & GFI & .98 & $>.90$ \\
\hline Root mean square error of approximation & RMSEA & .08 & $<.08$ \\
\hline Incremental fit measures & & & \\
\hline Adjusted good-of-fit index & AGFI & .92 & $>.90$ \\
\hline Tucker-Lewis index & TLI & .97 & $>.90$ \\
\hline Normed fit index & NFI & .98 & $>.90$ \\
\hline Comparative fit index & CFI & .99 & $>.95$ \\
\hline
\end{tabular}

Table 6 Regression Weights of the Hypothesized Causal Structure Model

\begin{tabular}{|c|c|c|c|c|}
\hline & $\begin{array}{l}\text { Unstandardized } \\
B \text { coefficient }\end{array}$ & S.E. & $\begin{array}{l}\text { Standardized } \beta \\
\text { coefficient }\end{array}$ & $t$-value \\
\hline $\begin{aligned} & \text { Electronic } \begin{array}{l}\text { Electronic } \\
\text { Service Quality }\end{array} \\
& \text { Recovery Service } \\
& \text { Quality }\end{aligned}$ & 1.23 & .14 & .62 & $8.73 * *$ \\
\hline 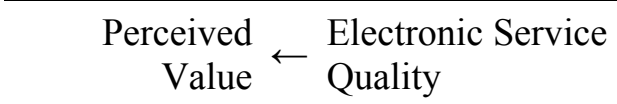 & .20 & .03 & .56 & $7.41 * *$ \\
\hline$\underset{\text { Satisfaction }}{\text { Customer }} \leftarrow$ Perceived Value & .43 & .05 & .75 & $9.13 * *$ \\
\hline
\end{tabular}


Table 6 Regression Weights of the Hypothesized Causal Structure Model (Continued)

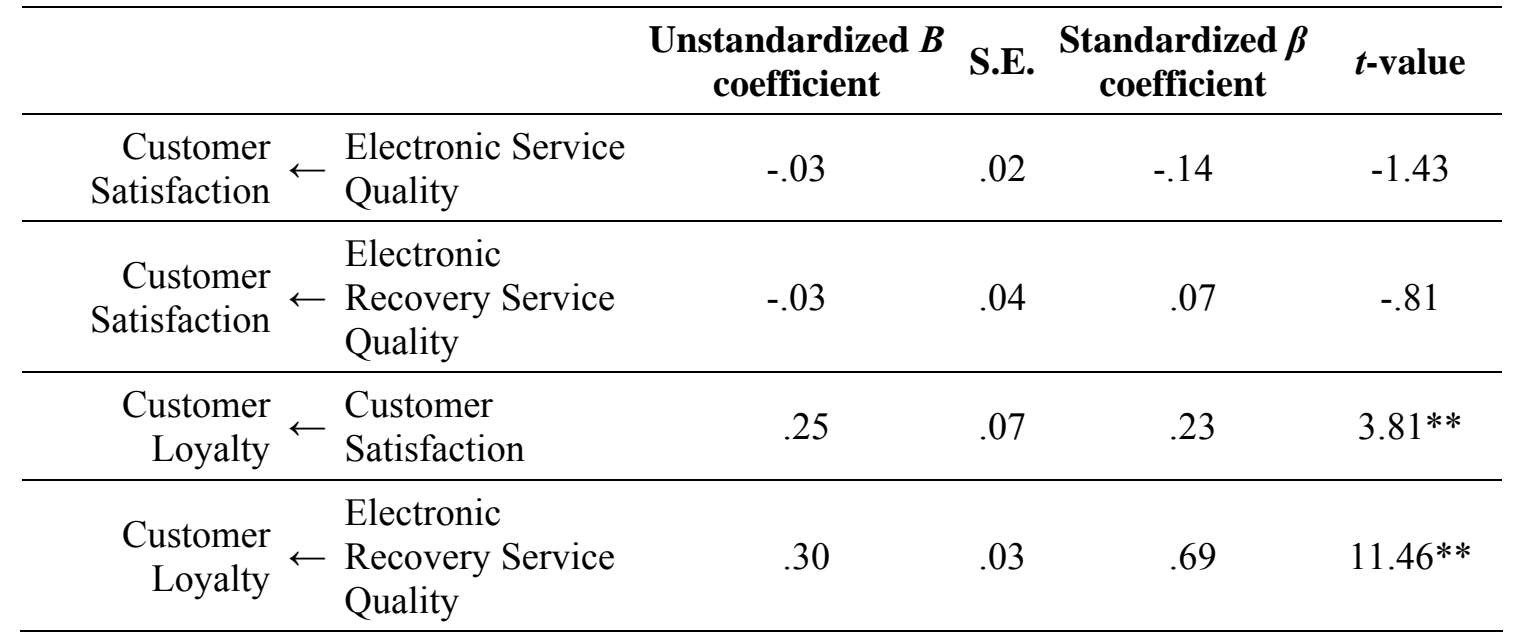

Note. $* * p \leq .01$

\section{The Hypothesized Causal Structure Model}

The results of the estimation of the hypothesized causal structure model indicated that the model well fit the sample $(\mathrm{GFI}=.98$, TLI $=.97$; NFI $=.98$; CFI $=.99)$. The majority of the goodness-of-fit indices were satisfied with their relative recommended thresholds. Compared to the study of Parasuraman, Zeithaml, and Malhotra (2005), this study had a lower RMSEA value of .08 than that reported in their work. Therefore, no further modification was needed. A summary of the goodness-of-fit results is presented in Table 5.

As shown in Table 6, the regression weight of electronic recovery service quality to customer satisfaction $(\mathrm{t}=-.81 ; p>.05)$ and electronic service quality to customer satisfaction $(\mathrm{t}=-1.43 ; p>.05)$ were not significant. This indicated that both electronic service quality and electronic recovery service quality had no significant direct effect on customer satisfaction. However, the unstandardized data were difficult to make comparisons with each effect. Using standardized data allows this study to compare the relative effect of each exogenous latent variable on the endogenous latent variable (Hair, Anderson, Tatham, \& Black, 1998). The analyses of direct, indirect, and total effects, as presented in Table 7, may help to understand how exogenous variables influenced endogenous variables.

In Table 7, it indicated that two direct effects were not significant: electronic recovery service quality to customer satisfaction (-.071) and electronic service quality to customer satisfaction (-.141). Four of six indirect effects were significant: electronic recovery service quality to perceived value (.349), electronic recovery service quality to customer satisfaction (.174), electronic service quality to customer satisfaction (.421), and perceived value to customer loyalty (.173). The results 
indicated that perceived value and customer satisfaction mediate the relationships among electronic service quality, electronic recovery service quality, and customer loyalty. Based on the goodness-of fit results and the results of analysis of direct, indirect, and total effects, every hypothesis in this study was supported except Hypothesis 4 and Hypothesis 6.

Table 7 Standardized Direct Effects, Indirect Effects, and Total Effects of the Hypothesized Model

\begin{tabular}{lllll}
\hline & $\begin{array}{c}\text { Electronic } \\
\text { Recovery Service } \\
\text { Quality }\end{array}$ & $\begin{array}{c}\text { Electronic } \\
\text { Service } \\
\text { Quality }\end{array}$ & $\begin{array}{c}\text { Perceived } \\
\text { Value }\end{array}$ & $\begin{array}{c}\text { Customer } \\
\text { Satisfaction }\end{array}$ \\
\hline Direct effects & $.623^{* *}$ & & & \\
\hline Electronic service quality & & $.560^{* *}$ & & \\
\hline Perceived value & -.071 & -.141 & $.750^{* *}$ & \\
\hline Customer satisfaction & $.693^{* *}$ & & & \\
\hline Customer loyalty & & & & \\
\hline Indirect effects & $.349^{* *}$ & & & \\
\hline Perceived value & $.174^{*}$ & $.421^{* *}$ & & \\
\hline Customer satisfaction & .024 & .064 & & \\
\hline Customer loyalty & & & & \\
\hline Total effects ${ }^{\mathrm{a}}$ & $.623^{* *}$ & & & \\
\hline Electronic service quality & $.349^{* *}$ & $.560^{* *}$ & & \\
\hline Perceived value & .104 & $.279^{* *}$ & $.750^{* *}$ & \\
\hline Customer satisfaction & $.717^{* *}$ & .064 & $.173^{*}$ & \\
\hline Customer loyalty & & & \\
\hline $\begin{array}{l}\text { Note. }{ }^{*} p \leq .05 ; \\
\text { a Total effects }=\text { Direct effects }+ \text { Indirect effects. }\end{array}$
\end{tabular}

\section{DISCUSSION}

The data analysis results indicated that electronic recovery service quality does not directly influence customer satisfaction, but directly influences electronic service quality and customer loyalty, and indirectly influences customer satisfaction. These findings do not support the empirical findings of Miller, Craighead, and Karwan (2000) and of Smith and Bolton (2002) that resolving customer problems has a strong impact on customer satisfaction. There are two perspectives to explain the unpredicted findings. First, customers directly gain loyalty from the process of service recovery. When they perceive higher service recovery quality, they turn a loyal customer to a specific e-tailer. Second, customers may expect to receive better services in the next 
transaction even though perceive higher service recovery quality. When they have better shopping experience in the next transaction, they have higher satisfaction and higher loyalty. This effect may result from customers forgive the e-tailer's mistake and accept its compensation.

This study found that perceived value and customer satisfaction mediates the relationships among electronic service quality, electronic recovery service quality, perceived value, and customer loyalty. In other words, electronic service quality and electronic recovery service quality influence behavioral intentions via perceived value and satisfaction. These findings in this study support empirical findings of Cronin and Taylor (1992, 1994) and Dabholkar, Shepherd, and Thorpe (2000).

According to the prior discussion, the hypothesized model was modified to the model presented in Figure 1. The modified model removed the arrows representing the relationship between electronic recovery service quality and customer satisfaction, and between electronic service quality and customer satisfaction.

\section{Limitations and Future Research}

There are some limitations in this study. First, the quota and snowball sampling methods are non-random, and may introduce sampling bias, threatening external validity. The results obtained by the quota and snowball sampling method were difficult to generalize to the population because a quota and snowball sampling method was a type of non-probability sampling and the socio-demographic characteristics of data-producing samples partially matched those of quota samples. Second, this study was primarily a cross-sectional study due to the constraints of cost and time, although a longitudinal approach is very important for a study of consumer behavior. Third, the findings cannot be generalized to other categories of e-tailers, such as e-tailers selling apparel, due to the difference in the nature of each industry. Fourth, the participants in this study may be active online survey respondents, and they may have completed a similar survey prior to participating in this study.

This study was limited to examining the causal relationships among electronic service quality, perceived value, customer satisfaction, customer loyalty, and electronic recovery service quality. In any future study, other significant variables, such as store image and profitability of the consumer electronics e-tailers, may be added into the hypothesized causal structural model. Moreover, future studies may use a different sampling method to collect data; for example, randomly selecting respondents from a list of customers of a specific e-tailer. 


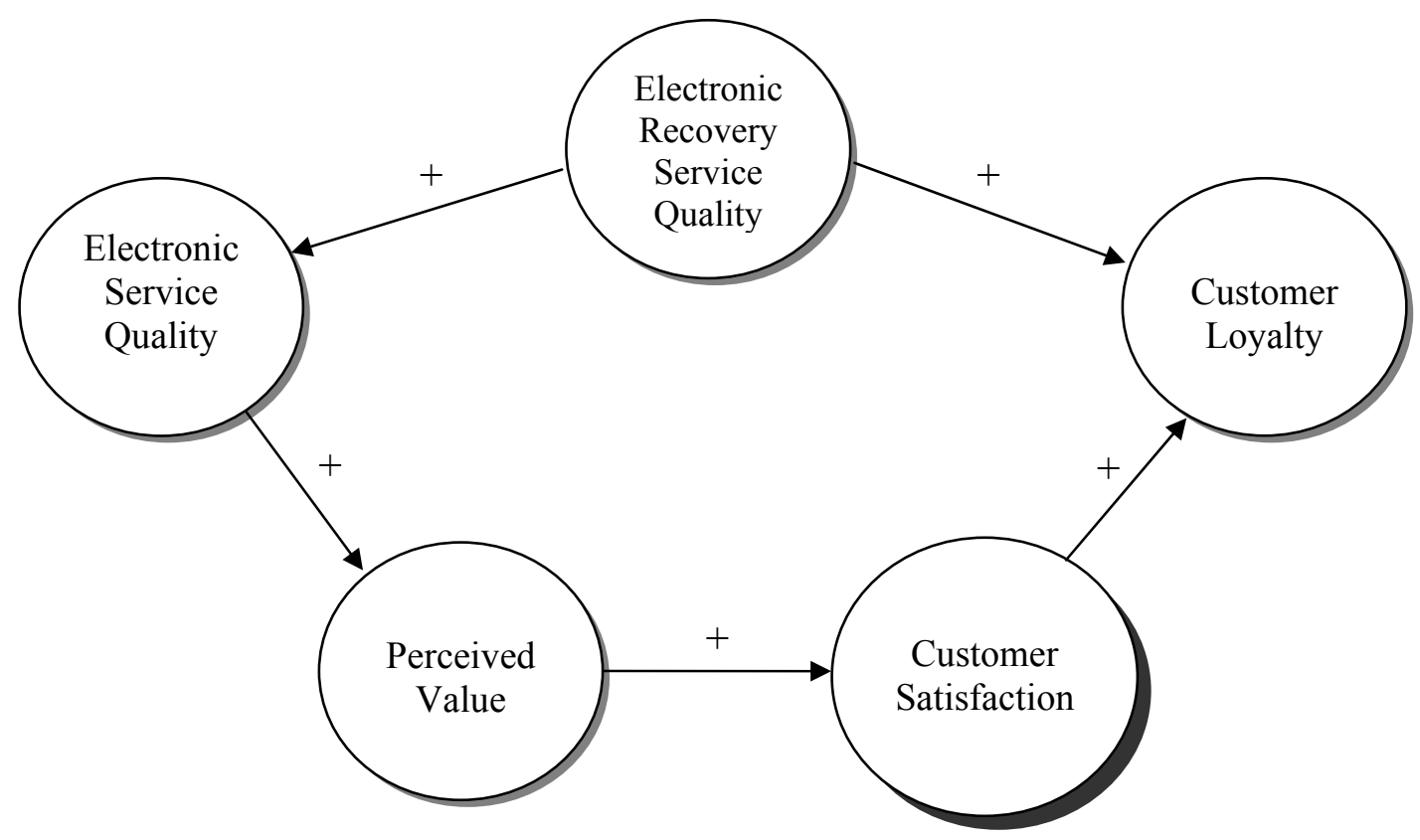

Figure 1 Modified Model

\section{Practical Implications}

Consumer electronics e-tailers could improve recovery service quality through the dimensions: responsiveness, contact, and compensation. Although electronic recovery service quality may not directly influence customer satisfaction, it may have an indirect effect on customer satisfaction via electronic service quality. The most important strategy to retain loyal customers is improving service recovery quality, such as alternative method to return products and quick response service failure. Consumer electronics e-tailing managers should be attentive to recovery service quality as much as they are to service quality and should therefore enhance complaint management.

Customer satisfaction has a direct effect on customers' behavioral intentions. Consumer electronics e-tailers' managers could develop a training program for customer service representatives to make a concerted effort to increase customer loyalty and reduce customer complaints. Moreover, consumer electronics e-tailing managers could formulate a competitive strategy based on the modified model to keep current customers and to enhance customer relation management.

\section{REFERENCES}

Anderson, E. W., \& Sullivan, M. W. (1993). The antecedents and consequences of customer satisfaction for firms. Marketing Science, 12(2), 125-143. 
Bennington, L., \& Cummane, J. (1998). Measuring service quality: A hybrid methodology. Total Quality Management, 9(6), 395-405.

Berry, L. L., \& Parasuraman, A. (1992). Prescriptions for a service quality revolution in America. Organizational Dynamics, 20(4), 5-15.

Bitner, M. J., Brown, S. W., \& Meuter, M. L. (2000). Technology infusion in service encounters. Journal of the Academy of Marketing Science, 28(1), 138-149.

Bloemer, J., \& Kasper, H. (1995). The complex relationship between consumer satisfaction and brand loyalty. Journal of Economic Psychology, 16(1), 311-329.

Bloemer, J., \& Ruyter, K. D. (1998). On the relationship between store image, store satisfaction and store loyalty. European Journal of Marketing, 32(5/6), 499-513.

Bonde, A., \& Cahill, D. B. (2005). Facilitating the move to Web self-service and optimized customer interactions. Retrieved December 18, 2005, from http://www.dmreview.com/article_sub.cfm?articleId=1032865

Bolton R. N., \& Lemon K. N. (1999). A dynamic model of customers' usage of services: Usage as an antecedent and consequence of satisfaction. Journal of Marketing Research, 36(2), 171-186.

Boulding, W., Kalra, A., Staelin, R., \& Zeithaml, V. A. (1993). A dynamic process model of service quality: From expectations to behavioral intentions. Journal of Marketing Research, 30(1), 7-27.

Byrne, B. M. (2001). Structural equation modeling with AMOS: Basic concepts, applications, and programming. Mahwah, NJ: Lawrence Erlbaum Associates, Inc.

Cöner, A., \& Güngör, M. O. (2002). Factors affecting customer loyalty in the competitive Turkish metropolitan retail markets. Journal of American Academy of Business, 2(1), 189-195.

Cox, B. (2002). Customer service still a struggle. Retrieved January 20, 2005, from http://dc.internet.com/news/print.php/947951

Cronin, J. J., Jr., \& Taylor, S. A. (1992). Measuring service quality: A reexamination and extension. Journal of Marketing, 56(3), 55-68.

Cronin, J. J., Jr., \& Taylor, S. A. (1994). SERVPERF versus SERVQUAL: Reconciling performance-based and perceptions-minus-expectations measurement of service quality. Journal of Marketing, 58(1), 125-131.

Dabholkar, P. A., Shepherd, C. D., \& Thorpe, D. I. (2000). A comprehensive framework for service quality: An investigation of critical conceptual and measurement issues through a longitudinal study. Journal of Retailing, 76(2), 139-173. 
Fornell, C., Johnson, M. D., Anderson, E. W., Cha, J., \& Bryant, B. E. (1996). The American Customer Satisfaction Index: Nature, purpose, and findings. Journal of Marketing, 60(4), 7-18.

Fredericks, J. O., \& Salter, J. M., II. (1998). What does your customer really want?. Quality Progress, 31(1), 63-65.

Girard, T., Korgaonkar, P., \& Silverblatt, R. (2003). Relationship of type of product, shopping orientations, and demographics with preference for shopping on the Internet. Journal of Business and Psychology, 18(1), 101-120.

Grossnickle, J., \& Raskin, O. (2001). The handbook of online marketing research. New York, NY: The McGraw-Hill Companies, Inc.

Hair, J. F., Jr., Anderson, R. E., Tatham, R. L., \& Black, W. C. (1998). Multivariate data analysis (5th ed.). Boston, MA: Pearson Education Inc.

Hart, C. W. L., Heskett, J. L., \& Sasser, W. E., Jr. (1990). The profitable art of service recovery. Harvard Business Review, 68(4), 148-156.

Holloway, B. B., \& Beatty, S. E. (2003). Service failure in online retailing: A recovery opportunity. Journal of Service Research, 6(1), 92-105.

Howard, M., \& Worboys, C. (2003). Self-service - A contradiction in terms or customer-led choice? Journal of Consumer Behavior, 2(4), 382-392.

Karlsson, T., Kuttainen, C., Pitt, L., \& Spyropoulou, S. (2005). Price as a variable in online consumer trade-offs [Abstract]. Marketing Intelligence \& Planning, 23(4/5), 350-358.

Kerner, S. M. (2004). More broadband usage means more online spending. Retrieved June 10, 2005, from http:/www.clickz.com/stats/sectors/broadband/ article.php/3419281

Luarn, P., \& Lin, H.-H. (2004). A customer loyalty model for e-service context. Journal of Electronic Commerce Research, 4(4), 156-167.

Millard, E. (2005). Online retail sales to surge in 2005. Retrieved December 26, 2005 , from http://www.cio-today.com/news/Online-Retail-Sales-To-Surge-in-2005/ story.xhtml?story_id=1000034INSV8

Miller, P. (2001). Tuning in to electronics: Catalogers pursue consumer electronics industry. $\quad$ Retrieved 16, March 2004, from http://www.findarticles.com/p/articles/mi_m3816/is_8_18/ai_76629652

Miller, J. L., Craighead, C. W., \& Karwan, K. R. (2000). Service recovery: A framework and empirical investigation. Journal of Operations Management, 18(4), 387-400. 
Minocha, S., Dawson, L. H., Blandford, A., \& Millard, N. (2005). Providing value to customer in e-commerce environments: The customer's perspective. Retrieved December 12, 2005, from http:/www.uclic.ucl.ac.uk/annb/docs/smldabnm Chappreprint.pdf

Nunnally, J. C., \& Bernstein, I. H. (1994). Psychometric theory (3rd ed.). New York, NY: McGraw-Hill, Inc.

Oliver, R. L. (1993). Cognitive, affective, and attribute bases of the satisfaction response. Journal of Consumer Research, 20(3), 418-430.

Oliver, R. L. (1997). Satisfaction: A behavioral perspective on the consumer. New York, NY: McGraw-Hill, Inc.

Oliver, R. L., \& DeSarbo, W. S. (1988). Response determinants in satisfaction judgments. Journal of Consumer Research, 14(4), 495-507.

Oliver, R. L., \& Swan, J. E. (1989a). Consumer perceptions of interpersonal equity and satisfaction in transactions: A field survey approach. Journal of Marketing, 53(2), 21-35.

Oliver, R. L., \& Swan, J. E. (1989b). Equity and disconfirmation perceptions as influences on merchant and product satisfaction. Journal of Consumer Research, 16(3), 372-383.

Parasuraman, A., Zeithaml, V. A., \& Berry, L. L. (1988). SERVQUAL: A multiple-item scale for measuring consumer perceptions of service quality. Journal of Retailing, 64(1), 12-40.

Parasuraman, A., Zeithaml, V. A., \& Malhotra, A. (2005). E-S-QUAL: A multiple-item scale for assessing electronic service quality. Journal of Service Research, 7(10), 1-21.

Raju, J. S., Srinivasan, V., \& Lal, R. (1990). The effects of brand loyalty on competitive price promotional strategies. Management Science, 36(3), 276-304.

Reidenbach, R. E., \& Sandifer-Smallwood, B. (1990). Exploring perceptions of hospital operations by a modified SERVQUAL approach. Journal of Health Care Marketing, 10(4), 47-55.

Robbins, T. L., \& Miller, J. L. (2004). Considering customer loyalty in developing service recovery strategies. Journal of Business Strategies, 21(2), 95-109.

Romano, P. S. (2004). Choosing study subjects and recruitment. Retrieved May 9, 2005, from http://som.ucdavis.edu/students/k30/folder.2004-06-21.4913658468/ 3ChoosingStudySubj.ppt

Sexton, R. S., Johnson, R. A., \& Hignite, M. A. (2002). Predicting Internet/ e-commerce use. Internet Research, 12(5), 402-410. 
Smith, A. K., \& Bolton, R. N. (2002). The effect of customers' emotional responses to service failure on their recovery effort evaluations and satisfaction judgments. Journal of the Academy of Marketing Science, 30(1), 5-23.

Spreng, R. A., \& Mackoy, R. D. (1996). An empirical examination of a model of perceived service quality and satisfaction. Journal of Retailing, 72(2), 201-214.

StatPat Inc. (2005). Sampling methods. Retrieved December 14, 2005, from http://www.statpac.com/surveys/sampling.htm

Supphellen, M., \& Nysveen, H. (2001). Drivers of intention to revisit the websites of well-known companies: The role of corporate brand loyalty. International Journal of Market Research, 43(3), 341-352.

Swanson, S. R., \& Kelley, S. W. (2001). Attributions and outcomes of the service recovery process. Journal of Marketing Theory and Practice, 9(4), 50-65.

Tax, S. S., \& Brown, S. W. (1998). Recovering and learning from service failure. Sloan Management Review, 40(1), 75-88.

Taylor, S. A. (1997). Assessing regression-based importance weights for quality perceptions and satisfaction judgments in the presence of higher order and/or interaction effects. Journal of Retailing, 73(1), 135-159.

Taylor, S. A., \& Baker, T. L. (1994). An assessment of the relationship between service quality and customer satisfaction in the formation of customers' purchase intentions. Journal of Retailing, 70(2), 163-178.

Teeter, C., \& Schointuch, B. (2000). Controlling Internet service quality. Credit Union Executive Journal, 40(6), 6-11.

Turow J., Feldman L., \& Meltzer K. (2005). Open to exploitation: American shoppers online and offline. Retrieved June 11, 2005, from http://www. annenbergpublicpolicycenter.org/04_info_society/Turow_APPC_Report_WEB_ FINAL.pdf

Woodside, A. G., Frey, L. L., \& Daly, R. T. (1989). Linking service quality, customer satisfaction, and behavioral intention. Journal of Health Care Marketing, 9(4), $5-17$.

Yang, Z. (2001). Measuring e-service quality and its linkage to customer loyalty. Dissertation Abstracts International. (UMI No. 3034679)

Zeithaml, V. A., Berry, L. L., \& Parasuraman, A. (1996). The behavioral consequences of service quality. Journal of Marketing, 60(2), 31-46.

Zeithaml, V. A., \& Bitner, M. J. (2003). Services marketing (3rd ed.). New York, NY: The McGraw-Hill Companies, Inc. 
Zeithaml, V. A., Parasuraman, A., \& Malhotra, A. (2000). A conceptual framework for understanding e-service quality: Implications for future research and managerial practice. Working Paper, No. 00-115. Cambridge, MA: Marketing Science Institute.

Zeithaml, V. A., Parasuraman, A., \& Malhotra, A. (2002). Service quality delivery through Web sites: A critical review of extant knowledge. Journal of Academy of Marketing Science, 30(4), 362-375. 
